\title{
Judicial Dispute Resolution in Canada: Towards Accessible Dispute Resolution
}

\section{Archie Zariski*}

This article argues that access to judges is an essential element of access to justice. Traditional civil litigation procedure aimed at preparation for trial that is complex, timeconsuming and costly obstructs such access, especially for litigants without lawyers. To remedy this, the author proposes a summary judicial dispute resolution procedure comprising two stages: early judicial intervention followed by judicial dispute resolution that is determinative if necessary. At both points litigants would be given the opportunity to settle their dispute consensually, thus combining principles of self-determination with final disposition according to law. The proposal draws on and extends contemporary innovations in Canadian courts concerning summary proceedings and binding judicial dispute resolution. The new procedure should improve access to judges and thus access to justice.

Dans cet article, l'auteur soutient que l'accès aux juges constitue un élément essentiel de l'accès à la justice. La procédure traditionnelle en matière civile, qui est axée sur la préparation en vue d'un procès complexe, long et coûteux, entrave cet accès, surtout pour les parties qui n'ont pas d'avocat. Afin de corriger cette situation, l'auteur propose une procédure sommaire de règlement des différends comportant deux étapes: une intervention judiciaire précoce, suivie au besoin d'un processus judiciaire qui permettra de sceller définitivement l'issue du litige. À chaque étape, les parties auraient la possibilité de régler leur différend de manière consensuelle, ce qui favoriserait l'application tant des principes de l'autodétermination que ceux du règlement final des litiges conformément à la loi. Inspirée au départ des récentes innovations introduites devant les tribunaux canadiens en matière de procédure sommaire et de règlement judiciaire contraignant des différends, cette proposition va plus loin et devrait permettre d'améliorer l'accès aux juges et, par le fait même, l'accès à la justice.

\section{INTRODUCTION - A SUMMARY JUDICIAL DISPUTE RESOLUTION PROCEDURE}

To withhold the equal protection of the laws, or to fail to carry out their intent by reason of inadequate machinery, is to undermine the entire structure and threaten it with collapse.

\footnotetext{
* Professor of Legal Studies, Athabasca University. A previous version of this paper was presented at a panel session of the Collaborative Research Network on Innovations in Judging at the Law \& Society Association Conference held in Toronto in June 2018. The author acknowledges the valuable feedback from participants in that session, particularly Bryan Clark and Debbie De Girolamo. Justice Robert A Graesser of the Court of Queen's Bench of Alberta kindly provided comments on a draft of the paper, and the questions and suggestions of the anonymous reviewers helped to improve the paper significantly. All remaining insufficiencies are my responsibility.
} 
The effects of this denial of justice are far reaching. Nothing rankles more in the human heart than the feeling of injustice. It produces a sense of helplessness, then bitterness. It is brooded over. It leads directly to contempt for law, disloyalty to the government, and plants the seeds of anarchy. The conviction grows that law is not justice and challenges the belief that justice is best secured when administered according to law. ... A persuasion spreads that there is one law for the rich and another for the poor. [footnotes omitted] ${ }^{1}$

Strong words, written one hundred years ago, which remain relevant and even more worrisome today when they apply to "everyone else" and not just "the poor."2 This realization makes it even more pressing to add a new interpretation to that well-worn acronym ADR - now let it be "accessible dispute resolution." It is time to fulfill the original promise of alternative dispute resolution to make justice both more accessible and more responsive by reforming the administration of civil justice. ${ }^{3}$

The late Frank Sander's vision of a "dispute resolution center" (later, a "multi-door courthouse") in 1976 featured a court that would act as a type of "justice broker" to select and refer lawsuits to the most appropriate resolution process. ${ }^{4}$ One of those processes was traditional litigation presided over by a judge, but it lay behind a different door than "alternative" processes such as mediation, arbitration, and fact finding. At this point in its evolution "ADR" was thought to exist separate and apart from the usual work of judges. As Sander noted, in the United States the litigation route was constitutionally entrenched by virtue of the Seventh Amendment which preserves the right to a jury trial in common law proceedings. For this reason, any alternative procedure required the consent of the parties, or at least their acquiescence through abandoning a demand for a jury trial. The shadow of the "jury trial" has cast a pall over courtconnected ADR not only in the United States, but in other jurisdictions, such as Canada, even though they lack the same constitutional entrenchment of formal adjudicative procedure. I suggest that this shadow has stymied attempts to introduce some of the practical benefits of more informal ADR procedures into conventional litigation. ${ }^{5}$ Although there are notable differences in legal culture and institutions between the United States and Canada, ${ }^{6}$ the American "ADR Movement" has undoubtedly influenced legal

1 Reginald Heber Smith, Justice and the Poor, (New York: Charles Scribner's Sons, 1919) at 5, 10.

2 Farrow has documented "a very negative and problematic class-based view of justice" amongst Canadians today. Trevor C W Farrow, "What is Access to Justice?” (2015) 2015 Revista Forumul Judecatorilor 72, 83.

3 Zemans notes "...the public still considers the courts the place to go to get what is their due. In the aggregate these individual interactions with a large proportion of the citizenry provides courts with both a burden and an opportunity. Courts have an opportunity to engender a broad base of support that is necessary to the operation of governmental institutions; at the same time, that extent of interaction also opens the courts to demands for accountability and for responsiveness from a broad base of the society.": Frances Kahn Zemans, "In the Eye of the Beholder: The Relationship Between the Public and the Courts" (1991) 15 Just Sys J 722, 724-25.

$4 \quad$ Frank E A Sander, "Varieties of Dispute Processing” (1976) 70 FRD 111.

5 The possibility of ultimate recourse to a jury trial may have an impact on the effectiveness of court-annexed dispute resolution processes such as settlement conferences. For instance, a difference in effectiveness between American and Canadian pretrial procedures was noted in Michael Stevenson et al, "The Impact of Pretrial Conferences: An Interim Report on the Ontario Pretrial Conference Experiment” (1977) 15:3 Osgoode Hall L J 591.

6 The author reviews these differences and the "mutations" in Canadian ADR arising from them in "The Multi-Door Courthouse at Middle Age: Life in Canada” (2019) 38:1 CJQ 44. 
developments in Canada. ${ }^{7}$ The argument of this paper is that the American preoccupation with the formal civil jury trial as "the basis for understanding our civil justice system", ${ }^{8}$ as one American commentator has phrased it, has obscured the potential in Canada for adopting less formal processes for the final determination of lawsuits. Although civil trials are increasingly rare in Canada as they are in the United States, ${ }^{9}$ the formal oral trial remains enshrined in court rules as the default endpoint of the litigation process. This procedural assumption frustrates efforts to provide more accessible dispute resolution through the courts. The Alberta Court of Appeal has recognized this reality:

[15] The theory that disputes eventually "went to trial" was always something of a legal fiction. Even when the court implied that a trial was called for, and declined to grant summary judgment, or declined to strike pleadings, it was well known that trials were a rarity. Hryniak $v$ Mauldin refers several times to the need for a change in culture. In other words, the myth of trial should no longer govern civil procedure. It should be recognized that interlocutory proceedings are primarily to "prepare an action for resolution", and only rarely do they actually involve "preparing an action for trial". ${ }^{10}$

Sander's vision of a multi-door courthouse appeared to preserve the "Superior Court" as a distinct avenue of redress conceptually and legally separate from the "alternative" resolution processes. However, as ADR gained respectability and acceptance amongst lawyers and judges many started to experiment with "crossover" procedures which brought ADR practices and procedures into the courts. Following the subsequent institutionalization of ADR in courts, there are now many variations of "court-connected," "courtsponsored" and "court-provided" ADR programs. One consequence of this melding of ADR and civil process has been to bring "dispute orientation" into litigation where it has coexisted uneasily with the traditional focus of courts on legal rights and obligations. This development has led to a second roadblock to the full institutionalization of ADR in courts in that lawyers and judges are largely left without guidance concerning the "non-legal" elements of disputes, commonly called "interests," that are appropriately dealt with in litigation. ${ }^{11}$

The shadow of the trial with its panoply of procedural formality and evidentiary rules has, for too long, frustrated attempts to provide more accessible justice within the courts. ${ }^{12}$ This promise of ADR has not

7 See, for instance the acknowledgment by a Canadian judge of borrowing (and modifying) the "mini-trial" process as practiced in American courts. Then Chief Justice Moore referred to a California handbook as being a guide for the process used in Alberta: William K. Moore, "Mini-Trials in Alberta" (1995) 34 Alta L Rev 194.

8 Robert A Patterson, "Reviving the Civil Jury Trial: Implementing Short, Summary, and Expedited Trial Programs" (2014) 2014 BYU L Rev 951 at 953.

9 See Marc Galanter, "The Decline of Trials in a Legalizing Society" (2017) 51 Val U L Rev 559.

10 Windsor v Canadian Pacific Railway Ltd., 2014 ABCA 108 at para 15.

11 Judges have been given some encouragement and guidance in ascertaining and working with litigants' interests in addition to their rights but many judges still appear reluctant to delve into them. See, for instance, Morton Denlow, "Breaking Impasses in Settlement Conferences: Five Techniques for Resolution" (2000) 39 Judges J 4; "Breaking Impasses in Judicial Settlement Conferences: Seven (More) Techniques for Resolution" (2010) 46 Ct Rev 130; "Settlement Conference Techniques: Caucus Dos and Don'ts" (2010) 49 Judges J 21.

12 Rooke describes the problem as being a conflict between "access to justice and the administration of justice" and believes judicial dispute resolution is the solution: John D Rooke, Improving Excellence: Evaluation of the Judicial 
been successfully integrated within civil litigation. ${ }^{13}$ Brazil puts it this way in arguing for judge-led dispute resolution:

We need to do what we can to encourage people to feel that their public institutions are useful to them. We also need to do what we can to encourage people to feel that the courts want to be just as accessible to them in economic fact as they are in political theory. By providing parties with useful settlement services, or at least by visibly trying to do so, we can demonstrate to litigants and lawyers that we really want to be of service and that we understand how difficult it can be, financially, to proceed through the ... court system. ${ }^{14}$

Speaking in a similar vein about mediation by judges, former Ontario Chief Justice Warren Winkler notes: "For the public, the issue, quite simply, is one of access to justice. A successful mediation can avoid a lengthy, expensive trial. Following this logic, the public expects this service to be provided to them without cost when they engage in litigation. Many are surprised when they have to dip into their own pockets to pay for pre-trial dispute resolution in relation to matters that to them seem to be appropriately within the realm of the courts." 15

Further, the promise of more participatory and personalized justice made by ADR has not been successfully combined with a civil litigation system focussed on legal rights. ${ }^{16}$ I argue that pioneering steps taken by some Canadian courts in offering "judicial dispute resolution" point the way to the changes

Dispute Resolution Program in the Court of Queen's Bench of Alberta (Evaluation Report) (Toronto: Canadian Forum on Civil Justice, 2009), online" $<$ http://www.cfcj-fcjc.org/sites/default/files/docs/hosted/22338-

improving_excellence.pdf $>$ at 425 [Rooke, Improving Excellence].

13 Rabinovich-Einy suggests that the "formal-informal" divide between traditional ADR processes and adjudication has become blurred, resulting in reduced legitimacy of courts as distinct fora with their own sources of legitimacy, which are not based on the parties' consent, or the principle of self-determination. She concludes that " $[t]$ he literature and the practical experience in the field of DSD [dispute systems design] have generated principles of design of dispute resolution systems, whose goals are dispute resolution, management and prevention. ... The future of courts therefore lies, not in restoring formality and reducing discretion, but in instituting design processes and quality control mechanisms that meet the principles described above. Orna Rabinovich-Einy, "The Legitimacy Crisis and the Future of Courts" (2015) 17 Cardozo J Conflict Resol 23 at 72. The procedure proposed here is an attempt to design a dispute resolution process well-suited to the courts.

14 Wayne D Brazil, "Hosting Mediation as a Representative of the System of Civil Justice" (2007) 22 Ohio St J Disp Resol 227, 241 [Brazil, "Hosting Mediation"]. See also Wayne D Brazil, "Informalism and Formalism in the History of ADR in the United States and An Exploration of the Sources, Character, and Implications of Formalism in a Court-Sponsored ADR Programme" in Zekoll et al, eds, Formalisation and Flexibilisation in Dispute Resolution (Leiden: Brill Nijhoff, 2014) 250 [Brazil, "Informalism"].

15 Warren K Winkler, "Some Reflections on Judicial Mediation: Reality or Fantasy?" (Distinguished Speakers Series delivered at University of Western Ontario, Faculty of Law, 24 March 2010), online: Court of Appeal for Ontario < http://www.ontariocourts.ca/coa/en/ps/speeches/reflections_judicial_mediation.htm>.

16 For an assessment of the ongoing debate concerning this question see Wayne D Brazil, "Rights and Resolution in Mediation: Our Responsibility to Debate the Reach of Our Responsibility" (2010) 16 Disp Resol Mag 9; For a Canadian view focussed on judicial mediation see Jacqueline Iny, “Judicial Mediation: Transformation or Transgression?" (2011) [unpublished, copy on file with the author]. Elnegahy compares the promise of "formal justice" with "creative justice" through mediation: Sherif Elnegahy, “Can Mediation Deliver Justice?” (2017) 18 Cardozo J Conflict Resol 759. 
we need to make to realize fully the benefits of ADR within the courts. The Ontario Bar Association has recognized the potential of judicial involvement in settling actions stating:

Improving Access to Justice - like any valuable form of mediation, JDR may have the potential to improve the affordability for individual clients and reduce over-all delay by moving resolvable cases out of the trial queue. We also sought to determine whether there is value in JDR being free to litigants (without additional cost, or even with savings, to the taxpayer where it can be done with existing resources). JDR may also provide an early opportunity for self-represented litigants to acquire some understanding of the system and the merits of their case from someone they associate with "their day in court"17

I will outline a vision of a new litigation procedure I have called "summary judicial dispute resolution procedure." In short, it combines some of the best attributes of ADR with the value of judicial participation and dispute determination if necessary, thereby enhancing both the practical and principled aims of justice. In this paper access to justice is conceptualized as the ability to invoke the aid of an authority with power to intervene in private affairs for the purpose of protecting legal rights or enforcing legal obligations. This echoes the definition used by researchers in the project "Measuring Access to Justice: The Hague Model of Access to Justice" who phrased it as "a situation in which a person may develop a need of a person for protection by outside norms or interventions that structure the conduct of another person that he may encounter or has a relationship with (justice need)." 18 The need or desire for justice originates in the wellknown behavioral pattern of "naming, blaming, and claiming" which the other party rejects or simply ignores. To the extent that the negative response (or lack of a response) is perceived as a sign of disdain or disrespect, a party may feel that not only have their legal rights been compromised but also their dignity as an equal member of society. A court then becomes a promising venue to vindicate both their legal rights and right to respect. Access to justice thus offers the possibility of obtaining both practical and symbolic benefits that must be weighed against the tangible and psychological costs of taking legal proceedings.

\section{A. Why "Summary"?}

We are told that trials were once prone to "ambushes" which required a party to respond to evidence that was unknown before presentation at trial. Absent an adjournment granted by the judge, the case might be won or lost on the surprise disclosure. To combat this litigation strategy rules were adopted to require discovery and disclosure of information and documents before trial. In response, lawyers dedicated to "vigorous advocacy" began to demand increasing amounts of documents and numbers of depositions in pursuit of a "no stone left unturned" policy of avoiding surprise at trial. As a reaction to the mass of potential evidence thus accumulated, courts then began to impose pre-trial conferences in the hope of

17 Ontario Bar Association, A Different 'Day in Court': The Role of the Judiciary in Facilitating Settlements (Taskforce Report) (Toronto: Ontario Bar Association, 2013), online: $<\mathrm{http} / / /$ www.oba.org/en/pdf/aDifferentDayInCourt7122013.pdf $>$ at 6.

18 Maurits Barendrecht et al, Priorities for the Justice System: Responding to the Most Urgent Legal Problems of Individuals (2008) Tilburg Institute for Interdisciplinary Studies of Civil Law and Conflict Resolution Systems Working Paper, online: SSRN <http://ssrn.com/abstract=1090885>. 
narrowing issues, agreeing upon facts, and otherwise planning for an efficient and shorter trial. The consequence to litigants of these procedural developments was to lengthen the period between pleading and trial and add substantial cost for factual investigations and judicial determinations of their relevance, adequacy and scope. The time required and cost of litigating in this modern mode are now significant elements contributing to the complexity of civil litigation. Although the scope of discovery in Canada is more limited than that in the United States, ${ }^{19}$ for many Canadian disputants these pretrial procedures impose substantial costs both materially and emotionally. ${ }^{20}$ In some cases plaintiffs may require discovery in order to substantiate their claims and advance towards resolution. Canadian courts have recognized this need and granted such requests when defendants have sought summary dismissal of claims. ${ }^{21}$ This is $^{2}$ another area in which Canadian and American procedure and practice seem to diverge. ${ }^{22}$

Courts have always had procedural means to make speedy decisions without extensive preliminaries but they have been underused. Pure issues of law might be quickly decided, but cases which present them without the necessity of much factual context are rare, or rarely considered by judges to arise. Summary judgment is a process which holds more promise because it may involve the determination of both law and fact. Several American jurisdictions have recognized this need and introduced procedures for shortened jury trials. ${ }^{23}$ The procedure proposed here is similar in some respects to such summary trials but without a jury.

Recently the Province of Ontario has amended its Rules of Court to make summary judgment more effective in bringing cases to final determination. The new rules empower judges to make findings of fact based on a combination of affidavit and oral evidence subject only to the necessity of considering whether a trial is necessary "in the interests of justice." In Hryniak v Mauldin, a complex case with multiple parties, appeals were taken from judgment rendered under this rule. The Supreme Court of Canada supported the procedure as an improvement in access to justice and noted that trial was not required in every case. Speaking for the Court Justice Karakatsanis began the judgment by noting:

19 See the summary prepared by one of Canada's national law firms: Osler, Hoskin \& Harcourt LLP, Introductory Guide to Civil Litigation in Ontario (Fact sheet) (Toronto: Osler, 2019), online: Osler $<$

https://www.osler.com/osler/media/Osler/reports/litigation/Civil-Litigation-in-Ontario-Introductory-Guide.pdf>.

20 Keet et al identify delay as a "major stressor in litigation" with adverse psychological impacts on litigants; Michaela Keet et al, "Anticipating and Managing the Psychological Cost of Civil Litigation" (2017) 34 Windsor YB Access Just 73 at 88.

21 In granting plaintiffs' applications to examine witnesses under oath (including a former Premier of the Province) and obtain documents from them for use in opposing summary dismissal of an action one Ontario judge stated:

[89] ... The plaintiffs are exercising rights they are entitled to exercise in responding to Ontario's motion for summary judgment. It is not an abuse of process to do so. Now that Ontario and OLG have brought motions to drive the plaintiffs from the judgment seat, it is not only open, but necessary for the plaintiffs as responding parties to put their best foot forward and to produce all evidence that could or should be available at trial. Seelster Farms Inc. v Ontario, 2017 ONSC 4756.

22 For insight into the current situation in America see Nancy A Welsh, "I Could Have Been a Contender: Summary Jury Trial As A Means to Overcome Iqbal's Negative Effects Upon Pre-Litigation Communication, Negotiation and Early, Consensual Dispute Resolution" (2010) 114 Penn St L Rev 1149.

23 Ibid, and see Patterson, supra note 8; National Center for State Courts, Short, Summary \& Expedited: The Evolution of Civil Jury Trials (Case Studies) (Williamsburg, VA: NCSC, 2009), online: NCSC <

https://www.ncsc.org/ /media/Files/PDF/Information\%20and\%20Resources/Civil\%20cover\%20sheets/ShortSummaryE xpedited-online $\% 20$ rev.ashx $>$. 
[1] Ensuring access to justice is the greatest challenge to the rule of law in Canada today. Trials have become increasingly expensive and protracted. Most Canadians cannot afford to sue when they are wronged or defend themselves when they are sued, and cannot afford to go to trial. Without an effective and accessible means of enforcing rights, the rule of law is threatened. Without public adjudication of civil cases, the development of the common law is stunted.

[2] Increasingly, there is recognition that a culture shift is required in order to create an environment promoting timely and affordable access to the civil justice system. This shift entails simplifying pretrial procedures and moving the emphasis away from the conventional trial in favour of proportional procedures tailored to the needs of the particular case. The balance between procedure and access struck by our justice system must come to reflect modern reality and recognize that new models of adjudication can be fair and just. ${ }^{24}$

There was apparently no argument that the new procedure offended litigants' due process rights to a judicial determination in accordance with fundamental justice under the Charter of Rights and Freedoms. Section 7 of the Charter provides that "Everyone has the right to life, liberty and security of the person and the right not to be deprived thereof except in accordance with the principles of fundamental justice." 25 This section has been held to apply to matters beyond the criminal law ${ }^{26}$ and to protect the right to a fair hearing "in the interests of justice." ${ }^{27}$ To date the courts have found the only procedural implication of this right in civil matters to be that a litigant must be given "an adequate opportunity to adequately state his case" 28 which may involve offering oral evidence especially when credibility is an issue, or alternatively "the opportunity to present his or her case effectively", which may involve state provision of legal representation. ${ }^{29}$

Some superior courts in Canada have approached the problem of providing expeditious and accessible resolution of legal claims starting from the ADR point of view. Courts in Alberta and Nova Scotia have adopted "hybrid" procedures in which judicial settlement conferencing is followed by binding determination by the judge if necessary. ${ }^{30}$ The Court of Appeal of Alberta has expressed similar sentiments to those in Hryniak while rejecting a challenge to the judicial dispute resolution program in the Court of Queen's Bench:

24 Hryniak v Mauldin, 2014 SCC 7 at paras 1, 2.

25 Canadian Charter of Rights and Freedoms, The Constitution Act, 1982, being Schedule B to the Canada Act 1982 (UK), 1982, c 11, s 7.

26 Blencoe v British Columbia (Human Rights Commission), [2000] 2 SCR 307 at para 45.

27 Ibid at para 120.

28 Singh v Minister of Employment and Immigration, [1985] 1 SCR 177 at 213-214.

29 New Brunswick (Minister of Health and Community Services) v G(J), [1999] 3 SCR 46 at para 73. See also J M Evans, "The Principles of Fundamental Justice: The Constitution and the Common Law" (1991) 29 Osgoode Hall LJ 51.

30 In Alberta there must be a prior contractual agreement between the parties to accept the judge's decision in the absence of a consensual settlement: $J$ W Abernethy Management \& Consulting Ltd $v 705589$ Alberta Ltd and Trillium Homes Ltd, 2005 ABCA 103; and this appears to also be the case in Nova Scotia: Forrest v Forrest, 2013 NSCA 15; Reece $v$ Reece, 2013 NSSC 33. 
[33] The appellants' view of JDR fails to recognize that judicial functions and processes must evolve to meet societal needs, in order to maintain confidence in and respect for the justice system. In Canada and elsewhere reports on the justice system have revealed concerns about inadequate access to justice because of the cost and time it takes to settle disputes in the courts....

[35] Queen's Bench has endorsed a multi-door approach by incorporating voluntary judicially facilitated settlement into its court processes. The move has been embraced by litigants, who "want to tell their story to a judge and hear a judge's opinion" in a setting less intimidating than a witness stand, and in a process less costly and time-consuming than a trial. See Promoting Early Resolution at paras. 179, 180. The immense popularity of JDR and its positive impact on access to justice strongly suggest the process should not be jettisoned because some litigants, lawyers and even judges disagree with particular JDR procedures. ${ }^{31}$

The positive attitude of some of the highest courts in Canada towards procedural innovation should be welcomed and built upon by courts throughout the country. ${ }^{32}$ The delay and expense associated with the preliminaries in civil litigation arising from an assumption that an oral trial will follow can and should be reduced. Summary procedures with alternative methods of fact-finding point the way. The proposal advanced here builds on the initiatives discussed above to streamline traditional adjudication while integrating ADR processes for the consensual resolution of disputes. Accessible dispute resolution should facilitate settlement if possible, but provide final determination if it is not. It should be noted that this proposal is designed for cases entering the superior courts and is not intended to replace other initiatives to provide proportional justice, such as small claims courts.

\section{B. Why "Judicial"?}

Courts, through providing access to justice, promise to bring law to bear on recalcitrant parties through the exercise of their authority while striving to treat parties with equal respect and attention. Litigants thus may seek both practical and symbolic recourse from judges to redress the economic and psychological

31 J W Abernethy Management \& Consulting Ltd v 705589 Alberta Ltd and Trillium Homes Ltd, 2005 ABCA 103, para 33, 35. For research that demonstrates the demand for judicial dispute resolution in Canada see John D Rooke, The MultiDoor Courthouse is Open in Alberta: Judicial Dispute Resolution is Institutionalized in the Court of Queen's Bench (LLM Thesis, University of Alberta Faculty of Law, 2010), online: <https://era.library.ualberta.ca/items/8f8a29e5-c9ec4067-b57f-1162eb6055f6> [Rooke, Multi-Door].

32 A judge of the Nova Scotia Court of Appeal, considering an appeal from the results of a binding settlement conference, remarked: "Courts recognize the importance of encouraging settlement and settlement oriented dispute resolution processes. Litigation is expensive and uncertain. It exhausts the resources of the parties and taxes those of the public who provide judges, courts and support staff. Less formal alternatives to trials should not be lightly cast aside. In this case, there were not extensive resources to fight about or with. Settlement was a sensible option. Mr. and Ms. Forrest were not required to agree to an alternative process, but on the facts before me, they were wise to do so." Forrest v Forrest, 2013 NSCA 15, para 22. 
harm they may have suffered through maltreatment by the opposing party. It is now well accepted that by providing the experience of procedural justice a decision maker may vindicate a disputant's dignity and feelings of self-respect even while declining to accept their claims. ${ }^{33}$ Increasingly, judges have become aware of the importance of this finding and what is sometimes called the experience of "procedural fairness." ${ }^{34}$ Judges and courts are now encouraged to monitor and improve their provision of procedural justice. ${ }^{35}$

Research has found that being treated with respect and understanding may be the most important component of the experience of procedural justice, ${ }^{36}$ and that procedural justice is more appreciated when it is supplied by a powerful, high ranking authority. ${ }^{37}$ Judges who provide procedural fairness, therefore, are in a unique position to satisfy litigants' yearning for respectful treatment while advancing their claims. ADR processes such as mediation conducted by non-judge neutrals, even when court-connected, have been criticized for their weakness in providing procedural justice. ${ }^{38}$ Thus, judges may have an advantage in securing both substantive and procedural justice for litigants if the obstacles of litigation complexity and cost are not too great.

Judges are the "face of justice" for most people just as court is the "place of justice." Countless studies have confirmed that for most litigants, speaking to a judge whether in a courtroom or a conference room satisfies their need for "a day in court." 39 Procedural justice studies provide an explanation for this observation. Interpersonal or relational effects are important in people's perceptions of whether legal processes in which they are involved are fair and just. Litigants want confirmation that they are being treated with respect as members of society and not as unworthy complainers or mere troublemakers. Judges are best placed to provide this social validation. Retired judges and mediators may well be respected by disputing parties but they do not have the same mantle of authority as sitting judges who

33 This finding stems from the work of Tom R Tyler and his associates. See, for instance, E Allan Lind \& Tom R Tyler, The Social Psychology of Procedural Justice (Dordrecht: Springer, 1988).

34 See a White Paper of the American Judges Association; Kevin Burke \& Steve Leben, "Procedural Fairness: A Key Ingredient in Public Satisfaction" (2007) 44 Ct Rev 4.

35 See for example, Nancy Welsh, Donna Stienstra \& Bobbi McAdoo, "The Application of Procedural Justice Research to Judicial Actions and Techniques in Settlement Sessions" in Tania Sourdin \& Archie Zariski, eds, The Multi-Tasking Judge: Comparative Judicial Dispute Resolution (Sydney: Thomson Reuters, 2013) 57; Procedural Fairness.org, Court Implementation (2019), online: < http://www.proceduralfairness.org/Court-Implementation.aspx>.

36 Tom R Tyler, "The Psychology of Procedural Justice: A Test of the Group-Value Model” (1989) 57:5 J Personality \& Soc Psych 830; Tom R Tyler, "Psychological Models of the Justice Motive: Antecedents of Distributive and Procedural Justice" (1994) 67:5 J Personality \& Soc Psych 850.

37 Henk A M Wilke, "Procedural Justice and Status: Status Salience as Antecedent of Procedural Fairness Effects" (2002) 83:6 J Personality \& Soc Psych 1353; Marius van Dijke et al, "The Role of Authority Power in Explaining Procedural Fairness Effects" (2010) 95:3 J Applied Psych 488.

38 Nancy A Welsh, "Making Deals in Court-Connected Mediation: What's Justice Got to Do With It" (2001) 79 Wash ULQ 787.

39 See for instance Joanne Goss, “Judicial Dispute Resolution: Program Setup and Evaluation in Edmonton” (2004) 42:3 Fam Ct Rev 511; Rooke, Multi-Door, supra note 31; Stephen G Crane, "Judge Settlements Versus Mediated Settlements" (2011) Disp Resol Mag 20. 
personify the justice system in the eyes of litigants. ${ }^{40}$ Courts and their judges are well suited to satisfy parties' craving for justice through the social sanctions of law and fair legal process. As Brazil puts it:

More subtly, clients whose cases are resolved by private negotiations can have no sense that a societal process solved their problem. They cannot feel that society set up machinery that they were able to use to repair a social tear. It is arguable that every time a dispute is resolved solely through private negotiations we have lost an opportunity to use the dispute resolution process as a means to help people feel more connected to and respectful of our society. ${ }^{41}$

Former magistrate judge Brazil was discussing early neutral evaluation and court-referred arbitration in addition to judicial settlement conferences when making these remarks. However, he noted that judicial involvement in settlement was a favored process and had the effect of encouraging the consideration of social values in addition to private interests. While use of arbitration has declined significantly, judicial settlement conferencing has remained a highly sought after process in the California court to which Brazil was attached such that today it is "rationed" with cases involving self-represented parties given priority of access to it. ${ }^{42}$

Scholars of access to justice in the Netherlands have expressed a similar view to that of Brazil. They make the point that

In an earlier paper, we showed how letting disputants agree on a procedure can be difficult (Barendrecht and De Vries 2006). Landes and Posner called this the "submission problem" in the context of letting the disputants choosing a private judge (Landes and Posner 1979). ... A transaction aimed at solving the dispute through mutually agreed upon methods poses a bargaining problem. ... If the parties fail to agree on a dispute resolution procedure, they may resort to other means of meeting their interests, including violence, or other abuses of power. ...

40 Galanter identified fourteen possible "qualitative" advantages of judicial involvement in dispute resolution including attribution of greater finality by the parties, "greater permeation by legal norms", moderation of lawyers' competitive style of negotiating, and greater perceived fairness by parties; Marc Galanter, "... A Settlement Judge, not a Trial Judge": Judicial Mediation in the United States" (1985) 12 J L \& Soc'y 1, 11-12 [Galanter, "Settlement Judge"]. See also Marc Galanter, "The Emergence of the Judge as a Mediator in Civil Cases" (1986) 69 Judicature 257.

41 Wayne D Brazil, "A Close Look at Three Court-Sponsored ADR Programs: Why They Exist, How They Operate, What They Deliver, and Whether They Threaten Important Values" (1990) 1990:1 U Chicago Legal F 303 at 330 [Brazil, "A Close Look"].

42 See United States District Court, Northern District of California, Alternative Dispute Resolution (ADR), (2019), online: $<\mathrm{http}$ ://www.cand.uscourts.gov/adr>; United States District Court, Northern District of California, ADR Handbook, (2019), online: <http://www.cand.uscourts.gov/adr/adr-handbook>. 
So from the perspective of transaction costs, giving people access to justice by allowing them to address a court seems to be a well founded policy. It lowers their transaction costs. Courts offer a valuable service that the parties cannot agree on themselves. ${ }^{43}$

In a study of the comparative value of social investment in legal aid, accessible courts or public legal education one of these researchers concluded

A judge without a lawyer is worth more than a lawyer without a judge, because many people will settle in the shadow of a court intervention. Moreover, the loss in outcomes by unrepresented litigants seems to be lower than the loss in outcomes by people who have to settle without a credible threat of judicial determination. ${ }^{44}$

Judges bring many practical skills and abilities to bear on the process of dispute resolution by virtue of their backgrounds and experience. These include:

- Legal knowledge gained through a substantial professional career

- Experience weighing and evaluating evidence and arguments

- Habit of impartiality and objectivity in dealing with competing positions

- Knowledge of litigation process and procedures

- Knowledge of local judicial attitudes and approaches ${ }^{45}$

Landerkin and Pirie describe the unique advantages of judges acting as dispute resolvers in these terms:

All judges will have an enormous amount of experience as adults living within their communities; through their own personal educational background, including post graduate training in law; profound skills learned at the bar as lawyers and counsel; knowledge of and being bound by ethical standards both in the legal profession and now as a judge, such standards being enforced in each case by sanction; and by actual judicial experience as decision-maker on the bench. The knowledge gained from a lifetime of experience, must, by law, sit idle at trial, following the rule of judicial notice. Absent knowledge of a notorious fact in the community, the adversarial adjudicative model leaves it to the parties

43 Maurits Barendrecht, Legal Aid, Accessible Courts or Legal Information? Three Access to Justice Strategies Compared (2010) Tilburg Institute for Interdisciplinary Studies of Civil Law and Conflict Resolution Systems Working Paper, online: SSRN $<$ http://ssrn.com/abstract $=1706825>$ at 10.

$44 \quad$ Ibid at 16.

45 Landerkin lists seven advantages of judges who act in a mediatory role including appreciation of "the necessity of balancing between disputants" and that "a judge understands better than most the limitations on people in terms of time, money, and emotion."; Hugh F Landerkin, "Custody Disputes in the Provincial Court of Alberta: A New Judicial Dispute Resolution Model” (1996) 35 Alta L Rev 627, 674. Wade suggests seventeen advantages judges may have over private mediators: John Wade, "Judicial Mediation and Competition for Clients and Government Funding among Dispute Resolution Providers" (2013) (Paper presented at Canadian Conference of Judicial Mediation Second General Assembly, Calgary, June 20-21, 2013) [unpublished, copy on file with the author]. 
to inform the trial judge of the issues, evidence and arguments. In the adversarial model, the trial judge sits above the well of the court and does not use this vast human experience, except to make credibility findings and in pronouncing judgment. With JDR there will be opportunities to take this vast store of knowledge off the judicial shelf and use it more fully in dialogue with the parties and counsel, as issues are explored and potential outcomes considered. Indeed, tapping into this judicial resource in the context of a settlement conference, mini-trial or other interaction focused on dispute resolution seems to be an important and unique benefit associated with JDR. ${ }^{46}$

In addition, increasing numbers of judges are acquiring interpersonal communication and other skills which are useful in dispute resolution processes. These may be learned while practicing as lawyers, or through judicial education programs after appointment to the bench. There is also now sufficient accumulated experience of judges acting as dispute resolvers to provide wise guidance for judges acting in this role. ${ }^{47}$

Judges are thus uniquely positioned to be able to provide both procedural and substantive justice to litigants. ${ }^{48}$ As Brazil argues, the involvement of a judge in cases that settle is also in the public interest:

There is no "public" involvement in or influence over settlements that are reached as -a result of negotiations in which only private litigants are involved. In a judicially hosted settlement conference, by contrast, there is at least an opportunity for a judge or magistrate to make dispassionate contributions to the analysis of the parties' situations and to

46 Hugh F Landerkin \& Andrew J Pirie, "Judges as Mediators: What's the Problem with Judicial Dispute Resolution in Canada?" (2003) 82 Can Bar Rev 249, 293.

47 See, for instance, Wayne D. Brazil, "Hosting Settlement Conferences: Effectiveness in the Judicial Role" (1987) 3:1 Ohio St J Disp Resol 1; James A Wall Jr \& Dale E Rude, "The Judge's Role in Settlement: Opinions from Missouri Judges and Attorneys" (1988) 1988 J Disp Resol 163; Susan M Gabriel, "Judicial Participation in Settlement: Pattern, Practice, and Ethics" 4 Ohio St J Disp Resol 81; William L Adams, "Let's Make a Deal: Effective Utilization of Judicial Settlements in State and Federal Courts" (1993) 72 Or L Rev 427; John Arnold Epp, "The Role of the Judiciary in the Settlement of Civil Actions: A Survey of Vancouver Lawyers" (1996) 15 Windsor YB Access Just 82; Royal Roads University, Peace and Conflict Studies Division, Whose Court is it Anyway? Judicial Dispute Resolution in Canadian Courts: A Symposium for Judges (Summary Report) (Victoria: Royal Roads University, 2003); John A Agrios \& Janice A Agrios, A Handbook on Judicial Dispute Resolution for Canadian Lawyers, (Handbook) (Toronto: Canadian Forum on Civil Justice, 2004) online: <http://www.cfcj-fcjc.org/sites/default/files/docs/hosted/18586-jdr_handbook.pdf>; Brazil, "Hosting Mediation", supra note 14; Hon Morton Denlow, "Settlement Techniques for Judges," (2001) [unpublished, archived at United States District Court Northern District of Illinois, on file with the author; Michaela Keet \& Brent Cotter, "Settlement Conferences and Judicial Role: The Scaffolding for Expanded Thinking about Judicial Ethics" (2012) 91 Can Bar Rev 363; Peter Robinson, “An Empirical Study of Settlement Conference Nuts and Bolts: Settlement Judges Facilitating Communication, Compromise and Fear" 17 Harv Negot L Rev 97; Ellen E Deason, "Beyond 'Managerial Judges': Appropriate Roles in Settlement" (2017) 78 Ohio St L J 73.

48 Epp found while investigating pre-trials in the Saskatchewan Court of Queen's Bench that "During a settlement pre-trial conference most judges will take an active role in ensuring that the settlement is fair. The majority of the respondents never 'allow settlements that might be, or are, unfair.' The reason most often given was that allowing such settlements was 'improper.'; John Arnold Epp, "Saskatchewan Pre-Trials: An Empirical Record and Proposed Amendments" (1991) 55 Sask L Rev 43, 61. 
encourage the litigants to consider social values and the implications for others of their settlement decisions. ${ }^{49}$

Wissler found that the American lawyers she surveyed generally preferred mediation with a non-judge neutral (typically a lawyer or retired judge) to settlement conferencing with a sitting judge, even if they were not assigned to try the case. ${ }^{50}$ Lawyers were concerned about the decision-making power of a judge, and the possibility of "leakage" of information from the settlement judge to the trial judge. However, the proposal advanced here does not envision significant decision-making at the first settlement-oriented phase of the dispute resolution process, and the author is confident that Canadian judges will preserve the confidentiality of that step as required by the proposed rules. Wissler further notes that litigants may have different priorities than lawyers, and accordingly could evaluate the settlement processes differently. Relis has indeed found that litigants put more emphasis on "non-fiscal, extra-legal objectives" including concerns for "dignity and respect after the injury, inability to be heard, refusal to listen, dismissal and victim blaming." ${ }^{51}$ For the reasons given above judges may be better able to satisfy parties' needs through providing the experience of procedural justice.

For all of these reasons, access to justice today crucially requires access to judges.

\section{Why "Dispute"?}

The disputing paradigm was introduced to the legal system by Frank Sander and other pioneers of ADR. It challenged lawyers and judges to look beyond their case files and court records to see the wider social context in which litigation exists. Viewed in this way, civil lawsuits represent just the tiny minority of the innumerable conflicts in society which are voiced, become disputes, and then are brought to the courts. Many interpersonal and social processes and influences contribute to this "escalation" of disputes into litigation. For a small fraction of this minority of disputes which enter the courts the deciding factor may be "principle:" the need to publicly affirm or establish a legal right or obligation which can serve as a precedent. For many disputes which become lawsuits a need is felt to obtain the leverage of the court to bring an opposing party who has rejected or ignored a claim for redress to the negotiating table. The ability for anyone to commence a legal claim is a hallmark of an accessible justice system under the rule of law. Then, once a lawsuit has begun, a credible threat to take it all the way to trial has long been recognized as giving significant leverage to a disputing party. ${ }^{52}$ However, an under-resourced (and perhaps unrepresented) litigant, whether in terms of knowledge, experience, or finances (a "have not" or a "one-

49 Brazil, "A Close Look", supra note 41 at 317-18.

50 Roselle L Wissler, "Court-Connected Settlement Procedures: Mediation and Judicial Settlement Conferences" (2011) 26 Ohio St J Disp Res 271.

51 Tamara Relis, "It's Not about the Money: A Theory of Misconceptions of Plaintiffs' Litigation Aims" (2007) U Pitt L Rev 701 at 721.

52 See for instance, Philip J Hermann, Better Settlements through Leverage (Rochester, NY: Aqueduct Books, 1965); Engel and Steele note that "Once a civil lawsuit is filed, the intricacies of pretrial procedure provide a new framework for negotiation, which is partially supervised by the court. Pretrial motions, discovery, and pretrial conferences provide strategic information as well as leverage in the negotiations, and cases are frequently settled at each of these points." David M Engel \& Eric H Steele, "Civil Cases and Society: Process and Order in the Civil Justice System" (1979) 1979 Am B Found Res J 295 at 309. 
shotter" in the well-known terminology) will find it difficult to convince a more empowered party to take such a threat seriously. Thus, to the extent that traditional civil litigation procedure leading to trial is complex, costly, and time consuming the leverage of willingness to take the opponent "to the mat" may be distinctly unbalanced. Such circumstances are fertile ground for coercive negotiation and unfair bargains far from the "shadow of the law," or simply "lumping it" without further legal recourse. ${ }^{53}$ Further, it has been found that many members of the public are unaware that today most cases settle before trial in any event. ${ }^{54}$ Thus, if they become litigants they are not in a good position to discount a threat of trial from opposing parties.

Marc Galanter famously coined the word "litigotiation" to describe civil litigation as a process of negotiation in the "shadow of the law" (another apt coined phrase). ${ }^{55}$ It is well to remember that the very rule of law itself is of particular benefit to plaintiffs who wish to bring powerful parties to account. Only a court has the power to require a party to answer for their actions in a public forum and to judge its legality. This is the "bargaining chip" which a lawsuit places in the hands of the plaintiff, and plaintiffs most often wish to use it to resolve their disputes as quickly and cheaply as possible. As discussed above, this may involve "a trial if necessary, but not necessarily a trial" as the saying goes. It is in this sense that the noted "Agent Orange" judge Jack Weinstein described the law as the protector of the powerless in society. ${ }^{56}$

But there is a downside to the strategic decision to convert a dispute into a lawsuit. In doing so, a party must find a way to fit their dispute into the framework of the law. In some cases it may simply not be justiciable and in many others the real nature of the dispute will be accommodated only roughly within a legal claim. Rights asserted may be overbroad in relation to felt needs and available remedies may be insufficient to undo harms experienced. Both difficulties may be exploited by the opposing party within the legal context and at the negotiating table.

Alternative dispute resolution scholars and practitioners have identified the problem of the lack of "fit" between disputes and litigation through use of the concept of "interests." As is now well known this term describes people's needs and concerns which should be taken into account and satisfied to the extent possible in processes of dispute resolution. Interests are not unknown to the law; they are recognized in the somewhat vague term "the public interest" and the marginally more specific one of "the best interests of the child." Outside of these limited instances, civil litigation is not formally concerned with advancing people's interests, but only protecting legal rights and enforcing legal obligations. Nevertheless, the legal

53 Steinberg found in her research that "While settlement is promoted across the civil spectrum, and often can be in the parties' best interests it reliably produces pernicious results for unrepresented litigants - particularly those who must negotiate with an attorney." [notes omitted]: Jessica K Steinberg, "A Theory of Civil Problem-Solving Courts" (2018) 93 NYU L Rev 1579 at 1599.

54 Galanter, "Decline of Trials," supra note 9 citing Marc Galanter \& Thomas Palay, Tournament of Lawyers: The Transformation of the Big Law Firm (Chicago: University of Chicago Press, 1991).

55 Galanter, "Settlement Judge" supra note 40.

56 See for instance Jack Weinstein, "The Role of Judges in a Government of, by, and for the People: Notes for the FiftyEighth Cardozo Lecture" (2008) 30 Cardozo L Rev 1, where he writes: “... the role of government - and the law - is in lending a hand to those who need it." at 149. Elnegahy notes the role of the formal justice system in "protecting the weak against the strong and achieving equal treatment and equalizing the power of the disputing parties." Elnegahy, supra note 16 at 767. 
system should not simply ignore the disputing paradigm with all its ramifications. A way must be found to make the process of "litigotiation," with the aim of satisfying parties' interests, both more just and more efficient.

There have been a number of attempts to make the concept of interests more understandable within, and adaptable to, the litigation context. One approach involves categorization of the nature of interests as substantive, procedural and psychological. ${ }^{57}$ Substantive interests accord most closely to the concrete results which litigation may yield such as damages or injunctions. Procedural interests concern the manner in which litigants are treated by the legal system and psychological interests involve needs related to people's personalities and behavioral systems. The former interests may be more easily accommodated within legal processes than the latter. Another way of looking at interests is to consider how they relate to the litigotiation process. From this perspective there may be barriers to agreement stemming from misinformation or misconceptions that legal processes may address in order to assist with settlement. The primary interests being addressed in this case are the need to reach resolution as fairly and expeditiously as possible. ${ }^{58}$

The legal system cannot afford to turn a blind eye to the disputing paradigm which is now well established in society. Courts and judges must find a way to support and assist the litigotiation process so that it is fair, just and satisfies litigants' interests to the extent possible within the law. ${ }^{59}$

\section{Why "Resolution"?}

In the vast majority of situations, when a disputant commences a lawsuit they are not seeking a trial. Rather they are looking for a fair resolution to the dispute with the help of the court - they are looking for finality. Justice Abella put it this way while serving on the Court of Appeal for Ontario:

The legal profession is taught that justice is procedural, which it partly is, and yet the public it serves procedurally wants justice of a more substantive kind. Getting there may be half the fun, but not if you are paying. Being there is what the public is interested in, being where the complaint can be resolved, and being heard there as soon as possible. Period. And if you can win too, so much the better. ${ }^{60}$

The ADR movement introduced the concept of resolution to the courts which were previously only concerned with adjudication. In association with the concept of dispute, the idea of resolution expanded the horizon of possible outcomes beyond the traditional remedies offered by law. While disputing expanded the range of issues beyond legal rights and obligations, resolution expanded the horizon of results which might be attained. The predominant ADR process of mediation allows consideration of

57 See Christopher Moore, The Mediation Process (San Francisco: Jossey Bass, 1986); Gary Furlong, The Conflict Resolution Toolbox (Mississauga: John Wiley and Sons, 2005).

58 There have been many attempts to conceptualize human conflict within legal contexts. One, adopted by Jeffrey Z Rubin consists of a triangle of conflict with "three Es" as its sides: Emotion, Environment, and Economy: Jeffrey Z Rubin as quoted in Elnegahy, supra note 16 at 771.

59 One scholar describes this as promoting "creative justice" through inviting the parties "to act creatively in crafting an outcome that presents their own sense of justice;" Elnegahy, supra note 16 at 770.

60 Rosalie Silberman Abella, "Professionalism in the Justice System: The Divine Comedy of Roscoe Pound" (2002) 51 UNBLJ 3 at 13. 
interests and creative solutions, but it rests on consensual settlement. Today all Canadian courts acknowledge and accept ADR processes such as mediation as appropriate alternatives to judicial determination, and some courts such as those in Saskatchewan provide the services of mediators. Nevertheless, resolution of lawsuits in this manner depends upon agreement being reached between the parties, and the fairness or quality of the resulting settlements are not monitored by the courts except in some family law matters.

A dispute resolution process provided by courts should be flexible enough to encompass solutions and remedies that could not be offered in traditional civil litigation, but effective enough to ensure that disputes are ended with the sanction of the law to back that up. As Wayne Brazil has noted, plaintiffs who are relatively powerless, especially those without lawyers, are often abandoned in a complex and lengthy pretrial process. Many simply give up. Brazil suggests that the court owes all parties a duty to assist with the progress of a lawsuit to the point that resolution can be achieved. It is not enough for the court to be open to all, it must also do what it can to make the process of dispute resolution practically available to all.

Judges need the ability to provide finality to disputing parties within a process that respects their interests as well as legal rights and obligations, without putting onerous procedural obstacles in the way. Canadian courts that have experimented with "binding judicial dispute resolution" or "binding settlement conferencing" show the way to achieving this goal. ${ }^{61}$

\section{E. Why "Procedure"?}

The ADR movement has always valued "informality" which is often considered to include flexibility in process and an absence of procedural rules. ${ }^{62}$ The benefits of flexibility in conducting mediation, for instance, are undeniable. They allow a mediator to "go with the flow" of the parties" discussions and negotiations in a way that complements rather than constrains them. Although some structure is usually advised in ADR processes, ${ }^{63}$ there is no agreement on optimum formats, and process steps are often chosen according to the personal preferences of the individual neutral. Ensuring process fairness and procedural justice in ADR processes outside the courts is therefore largely a matter of personal and professional ethics.

When dispute resolution is brought into the courts, however, other concerns are raised and constraints imposed. Courts and judges have duties to the law and the public which transcend the professional ethics of the individual judge. The administration of justice must be, and be seen to be, impartial and independent. Procedural rules in civil litigation and trial procedure exist in part to demonstrate that these values are being upheld, and thus help to secure respect for the legal system as a whole. Judges engaging in dispute resolution must be backed up by a minimum structure of procedural rules that do not stymie

61 In the case $J W$ Abernethy Management \& Consulting Ltd $v 705589$ Alberta Ltd and Trillium Homes Ltd, 2005 ABCA 103, the Alberta Court of Appeal approved a process whereby litigants might contractually agree to accept the decision of a judge on matters remaining in issue after conducting a settlement conference.

62 The emphasis on informality stems from the "community justice" strand of the ADR movement. For its influence on courts see Brazil, "Informalism", supra note 14.

63 See for example, O J Coogler, Structured Mediation in Divorce Settlement: A Handbook for Marital Mediators (Lexington, MA: Lexington Books, 1978). 
appropriate judicial actions, but which guarantee the public will accept that the judiciary as an institution is free from doubt or suspicion. ${ }^{64}$

The implementation of dispute resolution by judges within the courts began on an ad hoc basis but has gradually gained both wide acceptance and a formal place within the rules of procedure of many courts in Canada. Nevertheless, many of these rules regarding judicial dispute resolution remain overly broad and in many cases lack guidance for litigants of what to expect. ${ }^{65}$ In Alberta, for instance, the procedure to be followed in a judicial dispute resolution conference is left up to negotiation between the judge, counsel and parties. ${ }^{66}$ Alberta judges have resorted to indicating their personal procedural preferences which are published and provide some basis for selection of a particular judge when available. Arguably, this "personalizes" the administration of justice in a way that might be seen by some as incompatible with the rule of law. ${ }^{67}$

It is time for sufficient, but not complex, procedural rules to be adopted by Canadian courts for processes of judicial dispute resolution. ${ }^{68}$ Achieving consensus on these rules may be difficult but the effort is warranted by the goal - fully integrating the benefits of less formal ADR processes within the legal system in a way that benefits both litigants and courts. ${ }^{69}$

\section{F. Case Selection}

Selection criteria for court-connected ADR have been debated and disputed ever since Frank Sander suggested a "screening clerk" within the court who would direct cases to the appropriate resolution process. Case by case "triage" has not seemed practical although it seems to have been briefly tried in

64 Landerkin and Pirie anticipated the need for innovative procedures when judges were called on to act as mediators: "For example, procedural worries about judges stepping down from the bench into the mire of actual negotiations could be eliminated by mediating from the bench or other appropriate judicial venues, developing protocols which duly honour the office of judge in a mediation, mediating on the record, or, as in court, insisting on lawyer and party behaviours that raise the level of these negotiations to one that all participants can be proud of and respect.": Landerkin \& Pirie at 261. They also agreed with Stempel's opinion to the effect that "'streamlined mini adjudications' or 'focus points' hold greater potential for effecting judicial improvements than the settlement brokering or broad brush resolutions of large scale claims that seem to comprise so much of the judiciary's ADR efforts." (Referring to J Stempel, "Reflections on Judicial ADR and the Multi-Door Court House at Twenty: Fait Accompli, Failed Overture or Fledgling Adulthood?' (1996) 11 Ohio St J Disp Res 297.); Landerkin \& Pirie at 279.

65 This situation is not limited to Canada. See John C Cratsley, "Judges and Settlement: So Little Regulation With So Much at Stake" (2011) 17 Disp Resol Mag 4.

66 Alberta Rules of Court, AR 124/2010, Rules 4.17-4.21.

67 Justice Graesser of the Alberta Court of Queen's Bench has noted differences in the typical "style" of JDRs between those conducted in Edmonton and those in Calgary; Robert A Graesser, "Comparison between Judicial Settlement Activities and Those of Private ADR Professionals" (2010) [unpublished, on file with the author]. Associate Chief Justice Rooke notes that JDRs in Alberta can encompass a range of processes from "mini-trial" to a form of arbitration in a "binding JDR"; Rooke, supra note 31 at 21.

68 This is one of the key recommendations made in a report prepared by the Ontario Bar Association, supra note 17.

69 Menkel-Meadow worries that court-connected dispute resolution processes which she terms "semi-formal" in procedural terms are the "most problematic" with regard to appropriate regulation of such matters as "transparency, confidentiality or publicity, fairness, ethics, conflicts of interests, disclosures ..."; Carrie Menkel-Meadow, "Regulation of Dispute Resolution in the United States of America: From the Formal to the Informal to the 'Semi-formal'" in Steffek et al, eds, Regulating Dispute Resolution: ADR and Access to Justice at the Crossroads (Oxford, UK: Hart, 2013) 419 at 448-449. 
Ontario during a pilot project. 70 "Categorial" referral of cases based on areas of law implicated in them has been popular, especially for family law matters. Mandatory referral of all cases has also had some support, but also vigorous opposition. Referral by consent at either the instigation of the court or the parties' request is an easy way out. Despite continuing research, the superior effectiveness of any of these selection strategies has not been demonstrated, and consensus has not emerged.

I suggest that the goal of realizing the potential of ADR to increase access to justice should inform selection criteria. Based on that perspective the selection criteria for the judicial dispute resolution procedure proposed here should be based on parties' needs for assistance in navigating the civil litigation system in search of a fair result. ${ }^{71}$ That primary criterion would seem to lead to a focus on litigants without lawyers. ${ }^{72}$ In the United States Federal Court for the Northern District of California (formerly home to noted Magistrate Judge Wayne Brazil) this criterion has been adopted to assist with referral amongst ADR processes offered by the Court through its "multi-option" program. Parties without lawyers are given priority in judicially-hosted settlement conferences.

Applying the primary criterion of need for judicial intervention leads me to suggest the following scheme of priority selection, starting with mandatory referral:

70 Attorney-General of Ontario, Ontario Civil Justice Review First Report (Toronto: Attorney-General, 1995), online: $<$ https://www.attorneygeneral.jus.gov.on.ca/english/about/pubs/cjr/firstreport/index.php $>$. See also Thomas G Heintzman, "Court-Annexed Alternative Dispute Resolution: A Canadian Example" (Toronto: Heintzman ADR, 1996), online: Heintzman ADR <http://www.heintzmanadr.com/wp-content/uploads/Speech-Court-AnnexedAlternative-Dispute-Resolution-A-Canadian-Example1.pdf $>$.

71 One scholar notes "At the very least, with JDR there is a basic insurance that the process of negotiation is fair to all and that the settlement reached does not go against the basic rights of all parties. This is especially relevant in light of the increasing number of litigants who go to court without legal representation and therefore without clear knowledge of their rights or the law in general. For these parties, costs and time are often real considerations which would motivate them to settle. If the courts are trying to ensure access to justice to all, and provide a public service to society, it would seem useful and relevant to offer JDR services, which may allow parties to settle their dispute, saving time and money in doing so, but also to feel comforted by the fact that a judge oversaw the settlement discussions and the agreement reached."; Alexandra Otis, Judicial Dispute Resolution in Commonwealth Jurisdictions: Comparing the Evolving Judicial Role in Canada, Singapore and Australia (LLM Thesis, National University of Singapore, 2006), online: < https://scholarbank.nus.edu.sg/bitstream/10635/15179/1/Final\%20Version\%20LLM\%20Thesis\%2016\%20May\%202006 .pdf $>$ at 135 [footnote omitted].

72 In Canada there appear to be divergent views on the appropriateness of judge-led settlement procedures for litigants without lawyers. The Quebec Court of Appeal originally allowed such parties to access its mediation service, but has now apparently reversed that policy; Court of Appeal of Québec, Court of Appeal of Québec Mediation Service Program, (Fact Sheet) (Toronto: Canadian Forum on Civil Justice, 1998), online: Canadian Forum on Civil Justice < http://www.cfcj-fcjc.org/inventory-of-reforms/court-appeal-qu\%C3\%A9bec-mediation-service-program>. In Alberta, some Calgary judges will hear unrepresented parties in JDR proceedings, and some will not, see Court of Queen's Bench of Alberta, Judicial Assignments, online: Alberta Courts <https:/albertacourts.ca/qb/court-operations-schedules/judicialassignments $>$. See also Marguerite Trussler, "A Judicial View on Self-Represented Litigants" (2001) 19 Can Fam L Q 547. 
- Cases where all parties are without lawyers would be required automatically to proceed through the summary judicial dispute resolution procedure [SJDRP] $;^{73}$

- Cases in which at least one party is without a lawyer would be eligible for SJDRP at the request of that party; once requested the case would be required to proceed in SJDRP;

- Cases in which at least one party is without a lawyer would be eligible for SJDRP at the request of a represented party; leave would have to sought from a judge to refer the case and if the judge agreed the procedure would be useful the case would proceed in SJDRP;

- Cases in which no party is without a lawyer and all parties consented would be referred to SJDRP with leave of a judge;

- Cases in which no party is without a lawyer and one or more parties objected would be eligible for a party to apply to a judge for referral to SJDRP and that party would be required to show why the procedure would be especially effective or appropriate for the case.

The intent of this prioritization scheme for selection is to provide judicial assistance in those cases where it is expected to be most useful in reaching a fair and economical result. ${ }^{74}$ As Rankin suggests, traditional litigation culminating in trial presents judges with difficult issues of maintaining impartiality and decorum while assisting litigants without lawyers. ${ }^{75}$ The summary procedure advocated here would lessen that burden on the judiciary.

\section{G. Process Overview}

The suggested Summary Judicial Dispute Resolution Procedure [SJRDP] would feature two principal steps: Early Judicial Intervention [EJI] and Judicial Dispute Resolution [JDR]. They are intended to work together to promote the resolution of lawsuits in a timely and cost-effective manner while incorporating consideration of the parties' interests as well as their legal rights and obligations. ${ }^{76}$

73 The constitutionality of this selection process might be questioned, but given the flexibility afforded by Section 7 of the Charter as discussed above, and the special demands on courts made by unrepresented litigants it is submitted that any such challenge would fail.

74 The Alberta Court of Queen's Bench has taken a different approach when forced to "ration" judicial dispute resolution services by prioritizing family law matters. See Court of Queen's Bench of Alberta, Notice to the Profession NP\#201301, "Mandatory Dispute Resolution Requirement Before Entry for Trial" (12 February 2013). Because many family matters are conducted by litigants without lawyers, the practical effect of the selection criteria proposed here would not be that different.

75 Micah B Rankin, “Access to Justice and the Institutional Limits of Independent Courts" (2012) 30 Windsor YB Access Just 101.

76 Sinai and Alberstein describe this as a "dual-concern model" of dispute resolution: "It reflects the intersection between the legal world and the world of conflict resolution. The model represents the link between the legal world (including challenges to the idea of mechanical formalistic jurisprudence) and the conflict resolution world (including challenges to 
EJI would function as a combined procedural and settlement conference, incorporating features of traditional pre-trial management together with elements of early neutral evaluation. ${ }^{77}$ The combination of case management with settlement discussions has been criticized as blurring the focus of conferences and adding uncertainty for the parties. ${ }^{78}$ Nevertheless, attempts at settlement are encouraged by Canadian courts as part of existing pre-trial conferences. ${ }^{79}$ I argue that such a combination of purposes is warranted for the parties who will most likely be engaged in SJDRP. Litigants without lawyers especially need guidance concerning the law and procedures to be followed in pursuing their claims. The opportunity to provide this at an early stage in proceedings leads easily into a consideration of how those litigants expect to establish their claims and analysis of the legal and factual strengths and weaknesses revealed in such discussions. ${ }^{80}$ EJI should provide litigants both with a roadmap of the legal route they must take, and the risks and perils of the journey. ${ }^{81}$ It should also allow a judge to inquire into the needs and concerns which drive litigants so as to contribute wise and impartial assistance to any negotiations in which the parties' might wish to engage. Flatters describes such a process in these terms:

As a facilitator, the judge can assist the parties in focusing on interests in relation to legal rights, the theory of the case, the relief sought, narrowing the issues in dispute, and giving, in particular, a basis on which to evaluate the impartial judicial evaluation/opinion against their own position. Each opinion and evaluation gives a realistic view and risk management

the realistic positional bargaining perspective of conflict as a one-dimensional struggle for scarce resources." Yuval Sinai \& Michal Alberstein, "Expanding Judicial Discretion: Between Legal and Conflict Considerations" (2016) 21 Harv Negot L Rev 221 at 231. One experienced American judge considers expanded attention to interests to be a "holistic" approach: “... judges have to be aware that they are dealing with people, not just abstract ideas. People don't always behave in a predictable manner. ... We have to become more holistic. As judges, we have to think about things more broadly than the legislature tends to do when it's making general rules because the things we see in court are more personal and individualized." Jeremy Fogel \& S I Strong, "Judicial Education, Dispute Resolution and the Life of a Judge: A Conversation with Judge Jeremy Fogel, Director of the Federal Judicial Center" (2016) 2016 J Disp Resol 259 at 263-64.

77 Alexander describes a similar judicial settlement procedure in European jurisdictions as "judicial moderation" and likens it to settlement conferencing in Alberta as described by Flatters, Nadja Alexander, "Judges as Mediators" in N Alexander, ed, International and Comparative Mediation: Legal Perspectives (Alphen aan den Rijn: Kluwer Law International, 2009) 127, referring to Nancy A Flatters, "Family/Child Judicial Dispute Resolution (JDR): An Overview of One Canadian Court's Settlement Conference Approach to the Pretrial Resolution of Family and Child Welfare/Protection Matters" (2003) 41:2 Fam Ct Rev 182.

78 See Ontario Bar Association, supra note 17 at 21-22.

79 See for instance the remarks of the Court in Babich v Babich, 2017 SKCA 48.

80 One experienced Alberta JDR practitioner describes his intervention at this stage as follows: "Generally, I will provide a risk analysis, but with some comment as to where I see the risks and give a range of probabilities, qualified by the limited scope of the information before me and the time to spend with it. I will also invite the parties to question me on my analysis, which I think is one of the most valuable things that can be done for them at this stage." Robert A Graesser, "Judicial Dispute Resolution, Alberta Style" (2016) (Paper presented at Canadian Institute for the Administration of Justice, Forum on Mediation, Toronto, 29-30 April 2016), online: Canadian Institute for the Administration of Justice $<$ https://ciaj-icaj.ca/wp-content/uploads/documents/2016/05/m5.pdf?id=7733> [Graesser, "JDR Alberta Style"] at 6.

81 One American settlement judge observes that early intervention and evaluation may allow the parties to design a "settlement methodology" to be implemented after a judicial opinion is provided: Judge McCarthy as quoted in Steven J Miller, "Judicial Mediation: Two Judges' Philosophies" (2012) 38 Litig 31 at 32. 
appraisal of what a party may expect if the case proceeds to trial. The opinion of the judge is not binding, but the fact that it is the judge who is giving that opinion lends weight to the impartial opinion and evaluation that may bring about a settlement. It remains privileged, as does any draft proposed resolution that may be reached and not subsequently confirmed on the record or by order. The party can then make an informed decision as to whether to accept the impartial resolution and hence remain responsible for decision making. However, this work must be done with the judge still mindful of his or her role not only as a dispute resolver but as the bearer of societal normative norms and values whether this is in the public court setting or a settlement conference. ${ }^{82}$

Similarly, Roberge describes the judicial role in settlement as that of a "justice facilitator" who "develops a relationship of cooperation and trust between the parties to orient negotiations towards a fair solution that will generate a feeling of justice." ${ }^{83}$ However, the SJDRP differs from Roberge's vision of a purely facilitative role for judges that is well established in the courts of Quebec. ${ }^{84}$ Although a judge in the first EJI phase of the process might adopt a predominantly facilitative role, the judge at the second resolution stage will be required to be evaluative in providing a provisional judgment, and in approving any consensual agreements.

Associate Chief Justice Rooke of the Court of Queen's Bench of Alberta argues against early judicial intervention because of the " $95 \% / 5 \%$ principle" according to which $95 \%$ of all actions will terminate in any event before becoming ready for trial with little action required by the court. ${ }^{85}$ This position seems to assume that the great majority of cases are resolved by fair settlements "in the shadow of the law" rather than "in the shadow of penury or oppression." We simply do not know, and should not assume this. Former California Magistrate Judge Brazil takes a different view and suggests that the courts fail many less powerful or wealthy parties and those without lawyers whose claims are never considered on their merits. Their lawsuits are ripe for the imposition of imprudent settlement terms or dismissal for want of prosecution. Brazil counsels the courts to be proactive: "such litigants [the 'have-nots'] might be more inclined to try to use the judicial system if they - and their prospective counsel - could see that, relatively early in the pretrial period, the court would provide them - at little or no cost - a meaningful opportunity to address the merits of their dispute directly with the other parties and to try, with the aid of an experienced

82 Nancy A Flatters, "Family/Child Judicial Dispute Resolution (JDR): An Overview of One Canadian Court's Settlement Conference Approach to the Pretrial Resolution of Family and Child Welfare/Protection Matters" (2003) 41:2 Fam Ct Rev 182 at 190 (footnotes omitted).

83 Jean-François Roberge, The Sense of Access to Justice Following a Settlement Conference (Research Report) (Québec: Superior Court and Court of Québec, 2014), online: Tribunaux de Québec $<$ http://www.tribunaux.qc.ca/mjq_en/c-superieure/pdf/rech_exp_justiciables_cs_cq-a.pdf $>$ at 4.

84 See Jean-François Roberge, "'Sense of Access to Justice' as a Framework for Civil Procedure Justice Reform: An Empirical Assessment of Judicial Settlement Conferences in Quebec (Canada)" (2016) 17 Cardozo J Conflict Resol 323.

85 Rooke, supra note 31 at 25-26. 
neutral, to forge a settlement." 86 The author suggests the latter approach is more realistic and urges early judicial intervention accordingly. ${ }^{87}$

Most scholars of judicial dispute resolution argue that a judge who engages in separate private settlement discussions with the parties should not continue to make a binding determination in the case if that becomes necessary. ${ }^{88}$ Such a policy contributes to protecting the impartiality of the trial judge and encourages litigants to be forthcoming to the settlement judge during confidential caucuses. This ethical principle should form a key part of the proposed procedure.

The second, JDR phase, of the procedure would be conducted as a less formal hearing than a traditional trial, drawing on elements of summary trial procedure combined with aspects of judicial dispute resolution as currently practiced in some Canadian courts. ${ }^{89}$ The intent would be to allow the parties to attempt to establish their legal claims and defences without the procedural formality of a traditional trial and with the assistance of a more active, facilitative judge. Nevertheless, the hearing should be held in open court so that judges may be observed as contributing to improved access to justice for individuals by providing a fair and expeditious dispute resolution procedure. ${ }^{90}$ Current practice of judicial dispute resolution

86 Wayne D Brazil, "Should Court-Sponsored ADR Survive?" (2006) 21 Ohio St J Disp Resol 241 at 253.

87 The Court of Queen's Bench of Alberta has recently started a pilot project for early judicial intervention in family law matters that includes the promotion of settlement. See Court of Queen's Bench of Alberta, Notice to the Profession and Public, "Mandatory Early Intervention Case Conference Pilot Project for Family Law Matters" NP\#2016-08 (2016). In the Northwest Territory "judicial mediation" occurs at an early stage after the close of pleadings; Supreme Court of the Northwest Territories, "Judicial Settlement Conferences (Judicial Mediation)" (2018) (Pamphlet) (Yellowknife: Supreme Court of the Northwest Territories, 2018), online: Northwest Territories Courts

$<$ https://www.nwtcourts.ca/courts/PDF/judicial-mediation.pdf $>$.

88 See for instance, James J Alfini, "Risk of Coercion Too Great: Judges Should Not Mediate Cases Assigned to them for Trial" (1999) 6 Disp Resol Mag 1; Michaela Keet \& Brent Cotter, "Settlement Conferences and Judicial Role: The Scaffolding for Expanded Thinking about Judicial Ethics" (2012) 91 Can Bar Rev 363 at 366.

89 The Supreme Court of Nova Scotia conducts "binding settlement conferences" using a procedure discussed by one Judge as follows:

[2] My practice, followed in this case, is to discuss with the parties and their counsel (before commencing the task) certain concerns or restrictions that are inherent in the conduct of a binding settlement conference. This includes a discussion of possible roadblocks to an appeal of my decision, problems associated with the holding of 'caucus' sessions with the parties, restrictions on my ability to express an opinion on each of the issues as they are discussed and the fact that I will learn about compromises that each party is willing to make for settlement purposes which should not be disclosed to a Trial Judge even though I must after impasse adjudicate the issues if they are not agreed. After these potential shortcomings were raised on the record, I gave the parties an opportunity to speak privately with their counsel before confirming their willingness to proceed (which they did).

[3] The process is that I conduct a regular settlement conference with the hope of finding a settlement between the parties. When and if that fails, I utilize the authority given to me by the parties to impose on them a settlement of the issues as if I had conducted a trial relying on the affidavit evidence and the discussion held at the settlement conference to shape my decision.

Reece $v$ Reece, 2013 NSSC 33, para 2, 3.

90 The author agrees with Resnik's view of the value of openness in courts: "Judges gain legitimacy from being embedded in public exchanges as they exercise the power to direct the reallocation of property and the reorganization of families as well as to impose limitations on liberty. ... If third parties have no access to the processes and the impact of judges' actions (whether they are working in their roles as mediators, managers, or adjudicators), the rationales for judicial legitimacy, independence, and for significant public subsidies to courts weaken."; Judith Resnik, "The Contingency of 
includes meeting with unrepresented parties in open court and this should be continued. Parties would be allowed to confer privately for continuing settlement discussions, but the judge at this stage should always interact with them publicly. As structured below, the hearing would also allow consideration of the parties' interests in the hope that they might be accommodated in the result, but would provide a final determination in any event. ${ }^{91}$ JDR should be flexible, but also final.

\section{PROCEDURAL GUIDELINES}

As noted above, judicial dispute resolution in Canada would benefit from more precise procedural rules setting out the courts' expectations of the parties and the various functions to be performed by the judge. I argue that such rules are constitutionally within the legislative authority of the Provinces and further that it is likely they would be upheld by the Supreme Court of Canada if challenged under the Charter as being contrary to the principles of fundamental justice for reasons discussed above. The Supreme Court has recently demonstrated its willingness to permit procedural innovations in cases such as Endean v. British Columbia, ${ }^{92}$ where it approved superior court judges sitting outside their geographic jurisdictional boundaries, with or without video links back to their home Provinces. Speaking for the majority Justice Cromwell noted that it was important to recognize the power of a superior court "to regulate its proceedings in a way that secures convenience, expeditiousness and efficiency in the administration of justice." ${ }^{93}$

The SJDRP is designed to provide access to justice that is expeditious, effective and fair and should not run afoul of any constitutional provisions in Canada.

\section{A. Early Judicial Intervention}

Rules for EJI should be crafted to incorporate these matters:

- Scheduled soon after the close of pleadings (perhaps within 30 days) at which time it should be known whether parties have lawyers ${ }^{94}$

- Mandatory attendance by parties with settlement authority and their lawyers, if any

Openness in Courts: Changing the Experiences and Logics of the Public's Role in Court-Based ADR" (2015) 15 Nev LJ 1631 at $1636-1637$.

91 The procedure outlined here therefore differs from the purely facilitative model of judicial settlement processes in family law matters which Semple criticizes as being a misapplication of judicial resources: Noel Semple, "Judicial SettlementSeeking in Parenting Cases: A Mock Trial” (2013) 2013 J Disp Resol 301.

922016 SCC 42.

93 Ibid at para 60.

94 Neilson stresses the importance of early intervention in family law matters that may involve domestic violence; "Early resolution is thought to benefit families, children and the legal system; the stress of extensive adversarial litigation is avoided; court time is saved." Linda C Neilson, "At Cliff's Edge: Judicial Dispute Resolution in Domestic Violence Cases" (2014) 52:3 Fam Ct Rev 529. 
- Format to be a private conference for a relatively short time (perhaps one half day) with authority given to the judge to meet separately with parties and lawyers ("caucus") 95

- Confidentiality to apply to all discussions as being without prejudice; discussions in private sessions to be confidential and not divulged to other parties

- Judge's role and function to have several components:

$\circ$ Clarification of pleadings and narrowing of issues if possible

$\circ$ Analysis of necessary evidence to establish factual elements and obtaining agreement on facts if possible ${ }^{96}$

- Evaluation of strength of legal positions and possibilities for establishing necessary facts $^{97}$

- Invitation to express needs and concerns driving the litigation (interests) both confidentially and to opposing parties ${ }^{98}$

- Assistance if requested in negotiating possible settlement taking into consideration legal rights and obligations, judicial evaluations provided, and parties' interests ${ }^{99}$

95 The practice of caucusing with parties is controversial amongst the judiciary, but well recognized as a technique amongst dispute resolution practitioners. When the EJI judge is prohibited from presiding at the next phase of the procedure (see below), the advantages of this practice are seen to outweigh its problems. A leading scholar in the area of procedural justice supports this approach; Nancy A Welsh, "Magistrate Judges, Settlement, and Procedural Justice" (2016) $16 \mathrm{Nev}$ LJ 983. A leading Alberta judge who strongly supports JDR describes the benefit of caucusing as follows: "In the end result, in my experience, it is usually the detailed caucusing and shuttle communication that allows a judicial mediator to know how and when to use a number of mediation tools to improve the process of mediation to lead to settlement." John D Rooke, "Effective Mediation Through Shuttle Communication of Potentially Viable Proposals: After a Long Journey, Still Just a Beginner" (2016) (Paper presented at Canadian Institute for the Administration of Justice, Forum on Mediation, Toronto, 29-30 April 2016), online: Canadian Institute for the Administration of Justice $<$ https://ciaj-icaj.ca/wp-content/uploads/documents/2016/05/m4.pdf?id=7734> at 30 .

96 This may include agreeing upon an expert. See Agrios \& Agrios, supra note 47 at 20.

97 This aspect of the process mirrors that used in the Early Neutral Evaluation procedure of the United States District Court for Northern California; Brazil, "Informalism", supra note 14 at 295-301. It is noteworthy, however, that Canadian judges have been offering opinions on the merits of parties' cases in aid of settlement for many years in recognized procedures such as the "mini-trial" in British Columbia and the pre-trial conference in Ontario at least since the 1980s. See: D C Loeschmann, "Time, Gentlemen, Time ... Pre-Trial Conference Procedures in the Supreme Court of British Columbia" (1984) 18 UBC L Rev 163 at 172; R E Holland, "Pre-Trial Conferences in Canada" (1986) 7 Adv Q 416 at 423. Brazil aptly describes judges in this role as "analytically active"; Brazil, "A Close Look", supra note 41 at 311. One Alberta Queen's Bench judge has discussed the challenge facing judges in employing facilitative techniques appropriate to mediation within the context of a judicial settlement procedure which has an essential evaluative component; Lawrie Smith, "Seeing Justice Done: From Judicial Mediation to the Judicial Settlement Conference" (Paper presented to the National Judicial Institute, Judicial Settlement Conference, Vancouver, British Columbia, 15 October 2008) [unpublished, on file with the author]. The Associate Chief Justice of that Court however believes that JDR may appropriately consider both the rights and some "related" interests, at least, of the parties; Rooke, Improving Excellence supra note 12 at 44 .

99 Judicial intervention in negotiation may be robust. The Alberta Court of Appeal has stated "Trial judges do not enter the fray. A judge engaged in J.D.R. may do precisely that. Indeed, he or she may well exhort the parties and, on occasion, resort to gentle criticism in order to facilitate a fair compromise of disputed issues."; White $v$ White, 2003 ABCA 358, 
- Outcomes of the conference to include:

$\circ$ Orders amending pleadings

- Directions concerning factual matters to be proved, and form of evidence to be provided including scheduling disclosure

- Appointment of a joint or court expert either by consent or at the discretion of the judge

- Consent order or judgment or dismissal of the action if settlement is reached

- Setting a date for JDR

- Only records to be kept are orders made by the judge and the EJI judge should not discuss the conference with fellow members of the bench

- EJI judge must not preside at JDR of the case ${ }^{100}$

Some guidance concerning appropriate rules for EJI may be gained from the local rules governing early neutral evaluation in the Northern District of California ${ }^{101}$ together with pre-trial Rule 16 of the United States Federal Rules of Civil Procedure adapted to suit Canadian courts. ${ }^{102}$ One outcome of such a process might be that the parties are better prepared for a judicial decision which may or may not go their way. As has been noted, achieving that allows parties to potentially prepare alternative agreed upon solutions once a judge's conclusions on the substance of the case become known. This beneficial result is promoted by the JDR process described below.

The EJI process suggested here has some similarities to that of "compromise verdicts" found in the courts of Israel where the parties may invite the judge to take certain "extra-legal" factors including their interests into account in reaching a decision. ${ }^{103}$ However, at this stage of the proposed procedure the judge would be limited to providing suggestions for resolution and opinions concerning the likely outcomes of judicial determination based upon the parties presentations.

para 14. This aspect of the procedure proposed here is similar to early neutral evaluation as practiced in California since the 1980s but with a judge as the evaluator. See Wayne D Brazil et al, "Early Neutral Evaluation: An Experimental Effort to Expedite Dispute Resolution" (1986) 69 Judicature 279.

100 This is already the rule in several Canadian jurisdictions, subject to written waiver by all parties. See for instance Royal Bank of Canada v Hussain, 2016 ONCA 637; Alberta Rules of Court, AR 124/2010, Rule 4.21(1). The author accepts the cogent arguments made by Deason in support of a strict rule in these terms with no exceptions; Ellen E Deason, "Beyond 'Managerial Judges': Appropriate Roles in Settlement" (2017) 78 Ohio St L J 73.

101 United States District Court for the Northern District of California, ADR Local Rules (Rules of Court) (San Francisco: United States District Court for the Northern District of California, 2018), online: < https://www.cand.uscourts.gov/localrules/ADR>. See also Dispute Resolution Procedures in the Northern District of California (Handbook) (San Francisco: United States District Court for the Northern District of California, 2018), online $<$ https://www.cand.uscourts.gov/adr/adr-handbook>.

102 United States Federal Rules of Civil Procedure, online: <https://www.federalrulesofcivilprocedure.org/frcp/> Rule 16.

103 See Yuval Sinai \& Michal Alberstein, "Expanding Judicial Discretion: Between Legal and Conflict Considerations" (2016) 21 Harv Negot L Rev 221. 


\section{B. Judicial Dispute Resolution}

Rules for JDR should be crafted to incorporate these matters:

- $\quad$ Scheduled several months after EJI (perhaps within 90 days of that step)

- Mandatory attendance by parties with settlement authority and their lawyers, if any

- Format to be an open hearing in court ${ }^{104}$ with recording and all communications with the judge to be in the presence of other parties ${ }^{105}$

- Usual rules and procedures for in camera steps and confidentiality of information to apply

- Scheduled for a relatively short time (perhaps one day)

- Evidence to be presented through documents (affidavits, exhibits) except that each party be required to give their evidence under oath or affirmation; cross-examination to be permitted by questions submitted to and stated by the judge ${ }^{106}$

- Other oral evidence such as expert testimony to be permitted within the discretion of the judge

104 One study concludes that the location of proceedings in a courtroom has a positive impact on parties' favorable evaluation of a judicial process: Oscar G Chase \& Jonathan Thong, "Judging Judges: The Effect of Courtroom Ceremony on Participant Evaluation of Process Fairness-Related Factors" (2012) 24 Yale J L \& Human 221 at $233-234$. A JDR hearing in open court would also answer some of the concerns about the "vanishing judge" who conducts settlement proceedings in private or entirely based on documents. See Steven S Gensler \& Lee H Rosenthal, "The Reappearing Judge" (2013) 61 U Kan L Rev 849. Further, open hearings have been the accepted practice for some time in Alberta when litigants do not have lawyers representing them at JDR proceedings; Alberta Law Reform Institute, Alberta Rules of Court Project: Promoting Early Resolution of Disputes by Settlement (Consultation Memorandum) (Edmonton: Alberta Law Reform Institute, 2003), 92.

105 This approach is favored by a leading judicial proponent of JDR, Justice Robert A. Graesser of the Court of Queen's Bench of Alberta, who notes "I rarely caucus during binding JDRs as I am not comfortable receiving information from one side in the absence of the other, when I may have to make a binding decision on the matter or at least an issue." Graesser, "JDR Alberta Style", supra note 80 at 3.

106 The Alberta Court of Appeal has stated that "The JDR discussions afforded the judge an opportunity to assess the reasonableness of the parties' respective positions and of their credibility." and that "Surely, the JDR regime is flexible enough to allow the JDR judge to hear viva voce testimony from witnesses" in $L N v S M, 2007$ ABCA 258, paras 7, 36. In the Supreme Court of Nova Scotia a "binding settlement conference" may include oral evidence and crossexamination: Anderson v Renzetti, 2012 NSSC 361. Consideration should also be given to allowing oral evidence to be presented in an informal narrative format. 
- Judge's role and function to have several components:

$\circ$ Active supervision of the hearing including directions concerning issues to be dealt with and evidence to be adduced ${ }^{107}$

○ Questioning parties and other witnesses, if any

- Raising any maters which the judge requires to be dealt with so as to be in a position to make a decision ${ }^{108}$

- After all evidence and arguments have been heard the judge to indicate they are prepared to decide, either immediately or after a short time for preparation

- Judge to ask the parties whether they wish to discuss settlement before receiving a provisional decision and whether they wish the judge to assist them in that

- If the judge is requested to assist the proceedings remain in open court; if not, the parties may meet privately

- If no request regarding settlement is received the judge proceeds to deliver a provisional decision $^{109}$ and again asks whether the parties wish to discuss settlement taking it into account and whether they wish the assistance of the judge in doing so

- Again, if the judge is requested to assist the proceedings remain in open court; if not, the parties may meet privately

- Outcomes of the JDR to include:

- Conversion of the provisional decision into a binding order or judgment

- Amendment of the provisional decision in accordance with the parties' agreement subject to the approval of the judge and conversion into a binding consent order or judgment ${ }^{110}$

- Consent order or judgment as agreed by the parties, subject to the approval of the judge, in substitution for the provisional decision ${ }^{111}$

107 Such active facilitative judging has been observed and recommended both in lower level courts with self-represented parties and superior courts engaged in complex litigation. See Jessica K Steinberg, "Adversary Breakdown and Judicial Role Confusion in 'Small Case' Civil Justice” (2016) 2016 BYUL Rev 899.

108 In this respect the judge would proceed more along the lines of the active German "reporting judge" described in RMJ Werbicki, "The Pretrial Conference in the Supreme Court of Ontario" (1981) 59 Can Bar Rev 485 at 487-488.

109 This is similar to the practice of Justice Robert A. Graesser who delivers a "draft decision" in binding JDR proceedings: Graesser, "JDR, Alberta Style" supra note 80 at 5.

110 Requiring approval of the judge for any consent judgement or order made as a result of the final hearing ensures that judicial scrutiny is brought to bear on the substantive justice of the outcome according to law.

111 There is uncertainty concerning the status of the result of judicial settlement proceedings that should be resolved by clear rules such as recommended here. See Dueckman v Dueckman, 2013 ABCA 306. 
- According to normal practice only the judge's unmodified binding order or judgment would be appealable

This JDR process is intended to allow a judge to participate in a more facilitative way in less formal, more expeditious decision-making while not compromising the judicial role or ethics, or the dignity or openness of the court, but yet in a manner which may contribute to the achievement of better solutions for the parties. As indicated above, once the judge's provisional decision becomes known the parties may be prepared with solutions they have contemplated as a result of the EJI step. The judge is then well prepared to evaluate any proposed changes to their provisional decision which the parties may propose against the benchmark of the judge's application of the law to the facts which have been proved as stated in the provisional decision. The unique process of negotiation following decision making has an historical antecedent and is designed to allow maximum satisfaction of the parties' interests within the boundaries of what is legally acceptable.

The proposed JDR process has some similarities with the "mini-trial"112 and "binding" judicial dispute resolution as practiced in the Court of Queen's Bench of Alberta, but goes beyond them in providing for judicial determination in the absence of any agreed settlement. It is more similar to "binding settlement conferencing" practice in Nova Scotia but dispenses with the consent of the parties to engage in it. Of course, it also differs from any procedures in the United States because it is not constrained by the need to preserve final recourse to a jury trial. As described above, the parties would be free to raise their needs and concerns with the EJI judge, but not the JDR judge, at least before the judge reached a provisional decision. I suggest that this preserves the responsibility of the court to the law, while allowing the parties input concerning their interests within a framework of what has been established to be lawfully required in the circumstances of the case.

\section{CONCLUSION}

Canadian courts must rise to the challenge of remaining relevant as providers of civil justice to all those who are not wealthy or who do not represent powerful organizations, as well as providing accessible justice to individuals in family conflicts who have no alternative but the courts. It is time to step out of the shadow of the jury trial, or any traditional trial, and to embrace the informality and flexibility associated with ADR in a way that is compatible with the dignity and legitimacy of the courts. I suggest that in a constitutional system such as that in Canada, and likely, elsewhere, a re-design of civil litigation procedures can accomplish these goals within accepted constitutional and legal constraints as required by former Chief Justice Dickson. ${ }^{113}$ In their article "Judges as Mediators" Landerkin and Pirie note:

Chief Justice Dickson expressed a need to ensure the values underlying ADR, and by necessary implication JDR, 'are consistent with those that have evolved over many centuries and that lie at the heart of our judicial system' and that ADR (JDR) values be 'consistent with the principles of fundamental justice that underlie our judicial system.' He

112 See Alberta Law Reform Institute, Civil Litigation: The Judicial Mini-Trial (Discussion Paper) (Edmonton: Alberta Law Reform Institute, 1993); William K Moore, "Mini-Trials in Alberta" (1995) 34 Alta L Rev 194.

113 Brian Dickson, “ADR: The Courts and The Judicial System: The Canadian Context” (1994) 28 L Soc'y Gaz 231. 
identified values such as equal access, reliance on established procedures for equal treatment and dignity, reasoned decisions, openness to public scrutiny, and use of qualified neutrals and saw 'the decision to dispense with any one of these basic values should be the exception, not the rule.'" [footnotes omitted] (Referring to The Right Honorable Brian Dickson, "ADR: The Courts and The Judicial System: The Canadian Context" (1994) 28 L Soc'y Gaz 231. $)^{114}$

The Alberta Court of Appeal dismissed a jurisdictional challenge to the practice of Court of Queen's Bench judges making final decisions in "binding JDR" proceedings stating:

[22] As indicated in the previous section, there is authority to conduct JDR's under the Judicature Act, the Alberta Rules of Court, various Queen's Bench Practice Notes and the court's Guidelines for Judicial Dispute Resolution. The settlement process is flexible and no distinction is made between binding and non-binding JDR's. In fact, the Guidelines implicitly recognize both.

[23] Jurisdiction, authority, mechanisms and procedures are in place to encourage judges to settle disputes, and a binding JDR is one mechanism offered by the court. It is therefore a role a Queen's Bench judge reasonably could be expected to perform as part of his or her judicial duties and, in this case, was performed by the JDR judge in that capacity. Section 56(1) [of the Judges Act] was not contravened. ${ }^{115}$

The procedure recommended here also sufficiently satisfies the evaluation criteria proposed by Werbicki, in order of decreasing importance:

1. Procedure which the public accepts and respects, and in which it has confidence.

2. An independent and impartial judiciary.

3. Means which are accessible.

4. "Fairness, Justice, Due Process and Legality."

5. Proceedings which are public, visual and oral.

6. Procedure which produces a timely result.

7. An opportunity for review.

8. A simple but flexible system.

9. Development and publication of the common law. ${ }^{116}$

114 Hugh F Landerkin \& Andrew J Pirie, "Judges as Mediators: What's the Problem with Judicial Dispute Resolution in Canada?” (2003) 82 Can Bar Rev 249 at 292.

115 J W Abernethy Management \& Consulting Ltd v 705589 Alberta Ltd and Trillium Homes Ltd, 2005 ABCA 103, paras 22, 23.

116 Werbicki, supra note 108 at 500. The SJDRP also satisfies most of the "Quantitative or "Objective" Measures" and "Qualitative or Subjective Measures" proposed by Menkel-Meadow for assessing the success of a dispute resolution system including the time and cost of processing a case and perceptions of fairness, justice and trust in the institution; Menkel-Meadow, supra note 69 at 447-48. 
Some may suggest that the reforms proposed here are inconsistent with the "adversarial system" and too similar to "inquisitorial" processes as found in civil law jurisdictions. Perhaps they are, and so be it. They recall the approach of some European judges who begin their first meeting with the parties with the question: "If I decide this case in favor of one or the other of you, will that resolve all the problems between you?"117 If the unanimous honest answer is "yes" then it is a case that should go as quickly as possible to judgment. If the answer is "no" then it is a matter in which more comprehensive dispute resolution procedures are appropriate. Providing such dispute resolution in an accessible way then becomes the proper task of the court. ${ }^{118}$

The proposals advanced here are tentative; they deserve to be tested and the results observed. SJDRP combines the benefits of efficient, effective informal dispute resolution that meets peoples' needs with procedural and substantive fairness provided by the supervisory guidance of the law in the hands of wise judges. The outcomes reached through such procedure should exemplify access to justice at its best.

117 Christopher echoes this point of view when she suggests that when conducting dispute resolution proceedings judges should start "by asking what the parties are there to resolve, rather than what they are there to achieve." Michelle Christopher, "Judges and Settlement: Adding Value in Judicial Dispute Resolution" (2013) (Paper presented at Canadian Conference of Judicial Mediation Second General Assembly, Calgary, 20-21 June 20-21 2013) [unpublished, copy on file with the author] at 9.

118 For a review of judicial settlement approaches in civil law jurisdictions see Alexander, supra note 77. 